Galaxea, JCRS, 2: 43 - 50 (2000)

\title{
石垣島宮良湾の裙礁礁池における塊状ハマサンゴの分布特性
}

\section{The distribution of massive Porites in the moat of Miyara fringing reef, Ishigaki Island, Japan}

\author{
佐藤崇範 ${ }^{1}$ ・堀 信行 ${ }^{1}$ - 鈴木 淳 $^{2}$ \\ T. Satoh ${ }^{1}$, N. Hori ${ }^{1}$ and A. Suzuki ${ }^{2}$ \\ 1 東京都立大学大学院理学研究科地理科学専攻 \\ ${ }^{1}$ Department of Geographical Science, Tokyo Metropolitan University \\ 2 工業技術院地質調査所海洋地質部 \\ 2 Marine Geology Department, Geological Survey of Japan, \\ Agency of Industrial Science and Technology
}

\begin{abstract}
The spatial distribution and morphologies of massive Porites colonies were investigated over a large area $(1100 \mathrm{~m} \times 200 \mathrm{~m})$ in the sandy moat of Miyara fringing reef, Ishigaki Island, Japan. Massive Porites (diameter $>50 \mathrm{~cm}$ ) showed a preferential distribution for deeper depths (i.e., 2 to $3 \mathrm{~m}$ ). This distribution pattern suggested that massive Porites colonies were transported to deeper more stable habitats, as "mobile colonies". Twenty-three percent of the colonies were mushroom shaped, with narrow stems attached to the substratum. Significant portions of mushroom shaped colonies (69\%) were dislodged and $66 \%$ of them were tilted toward the dominant direction of water flow. The mushroom morphologies appear related to the high mobility of sandy sediments around the colonies, which interferes with ordinary growth of the colony base. Mobile colonies seems important for maintaining local coral populations in sandy habitats, which are often unsuitable habitats for larval settlement. In this case, physical environmental factors, such as water movement and micro-geomorphology, influence the distribution and population structure of coral communities in the sandy shallow habitats.
\end{abstract}

Key words: massive Porites, moat, mobile colony, water movement, micro-geomorphology

はじめに

砂質・砂碟質の堆積物で覆われている裾礁礁池は、固 着性生物の着底基盤としては不安定であるため、造礁サ ンゴの被度は一般的に低い（Takahashi et al. 1985）。 しかし、多くの礁池では八マサンゴ属（Genus Porites） なごの大きな塊状群体が特徴的に観察される（中森 1991）。 Highsmith（1980）は、塊状ハマサンゴが不安定な基盤 上にもみられる理由として、破片化（fragmentation） によって無性生殖的に加入し、生存する可能性が高いた めであるとした。このことは、塊状八マサンゴが幼生の 加入に適さない海域における造礁サンゴ群集のパイオニ ア種となり、他の生物の幼生が着底可能な安定した基盤 を提供することを示唆する (Highsmith 1980; Done and
Potts 1992)。また、不安定な砂質底に塊状八マサンゴが 加入し成長することは、群体の接地面において基盤を安 定化させ、礁池内の大型構造物として堆積物の移動・再 堆積に影響を及ぼすことから、サンゴ礁内の地形形成に 果たす役割む大きいと考えられる (Hopley 1982)。その ため、塊状ハマサンゴ群の分布構造を把握することは、 礁池内の微地形形成や群集形成を考える上であ重要であ る。

ところで、分布密度が低く、群体径が大きい礁池の塊 状ハマサンゴの分布を定量的に把握するためには、低被 度地域を広範囲にわたって調查する必要がある。現在、 造礁サンゴ類の被度や群集構造の調査には、コドラート 法やベルトトランセクト法などが多く用いられている。 しかし、方形区の一辺、もしくはベルトの横幅は通常 1 
〜 $2 \mathrm{~m}$ 程度であり、直径が数メートルに達するような群 体について定量的なデータをえるためには有効な調查法 ではない。また、サンゴ群集を広範囲にうたって定量的 に把握する調查法は、大規模コドラート（10 $50 \mathrm{~m}$ 四方 の方形区）を用いたもの（Fujioka 1999）、メジャーとコ ンパスを用いたマイクロアトールの分布調査（長谷川・ 長谷川 1998）などごく一部の研究で試みられているのみ である。

そこで本研究では、礁池内における造礁サンゴの分布 と微地形との関係を把握するための第一段階として、礁 池における塊状八マサンゴの分布を広範囲において調査 し、その分布特性と環境条件、特に微地形および海水の 流動との関わりを検討する。なお本研究では Done and Potts（1992）にならい、塊状の生活型を示すコブハマサ ンゴ (Porites lutea)、ハマサンゴ ( $P$. australiensis)、 フカアナハマサンゴ ( $P$. lobata) の 3 種を一括して「塊 状ハマサンゴ」とよび、一つの分類群として取り扱う。

\section{調查地域の概要}

本研究は、琉球列島南西部に位置する石垣島の宮良湾 東岸（図1 a) の礁池を対象として行なわれた。石垣島東 海岸には、幅数百メートルの裾礁が連続的に発達してお り、本調查地域はその裾礁の南端部に位置する。宮良湾 には、於茂登山系にその源を発する宮良川（流域面積： $35.4 \mathrm{~km}^{2}$ 流路延長 : $12 \mathrm{~km}$ ) が北側から流入しており、河 口から南西方向に通称「ミヤラグチ」と呼ばれる水道が 形成されている。

\section{方 法}

\section{地形区分}

現地調査では、海岸線に直行する測線を設け、距離 25 m間隔で地形断面測量を行った。また地形の起伏が著し い地点においても随時測深を行った。測点の深度は石垣 港の潮候曲線を参考に時刻補正を行い、平均海面加らの 水深を求めた。さらに地形断面測量の結果之国土地理院 1995年撮影のカラー空中写真（縮尺 1 万分の 1 ）（図1b） の判読結果から、調査地域のサンゴ礁微地形分類図を作 成した（図 $2 a) 。$

\section{塊状ハマサンゴの分布・外形調查}

予察調査において、塊状八マサンゴは礁池の中でも特 に海岸に近い部分に比較的多くみられ、外洋側ではほと んど観察されなかった。そこで分布調査は、海岸から沖 合にかけて塊状八マサンゴがほとんど確認できなくなる 範囲、すなわち海岸線から沖合方向に約200〜300 m、平 行方向に約 $1,100 \mathrm{~m}$ の範囲で行った（図 $1 \mathrm{~b})$ 。調查時にお ける海域の水平方向の透視度に応じた間隔（約 10〜 $15 \mathrm{~m} ）$ で調査区内を海岸線と直交方向に往復し、塊状ハマサン ゴを探索した。群体の位置測量および生育状況の調査は、 長径 $50 \mathrm{~cm}$ 以上の群体を対象として行い、長径 $50 \mathrm{~cm}$ 未満の 群体については、目視観察により分布状況等を随時記録 するにとどめた。群体の位置測量には、光学距離測定器 (LYTESPEED 800, BUSHNELL; 測定䛊差 1 m) と
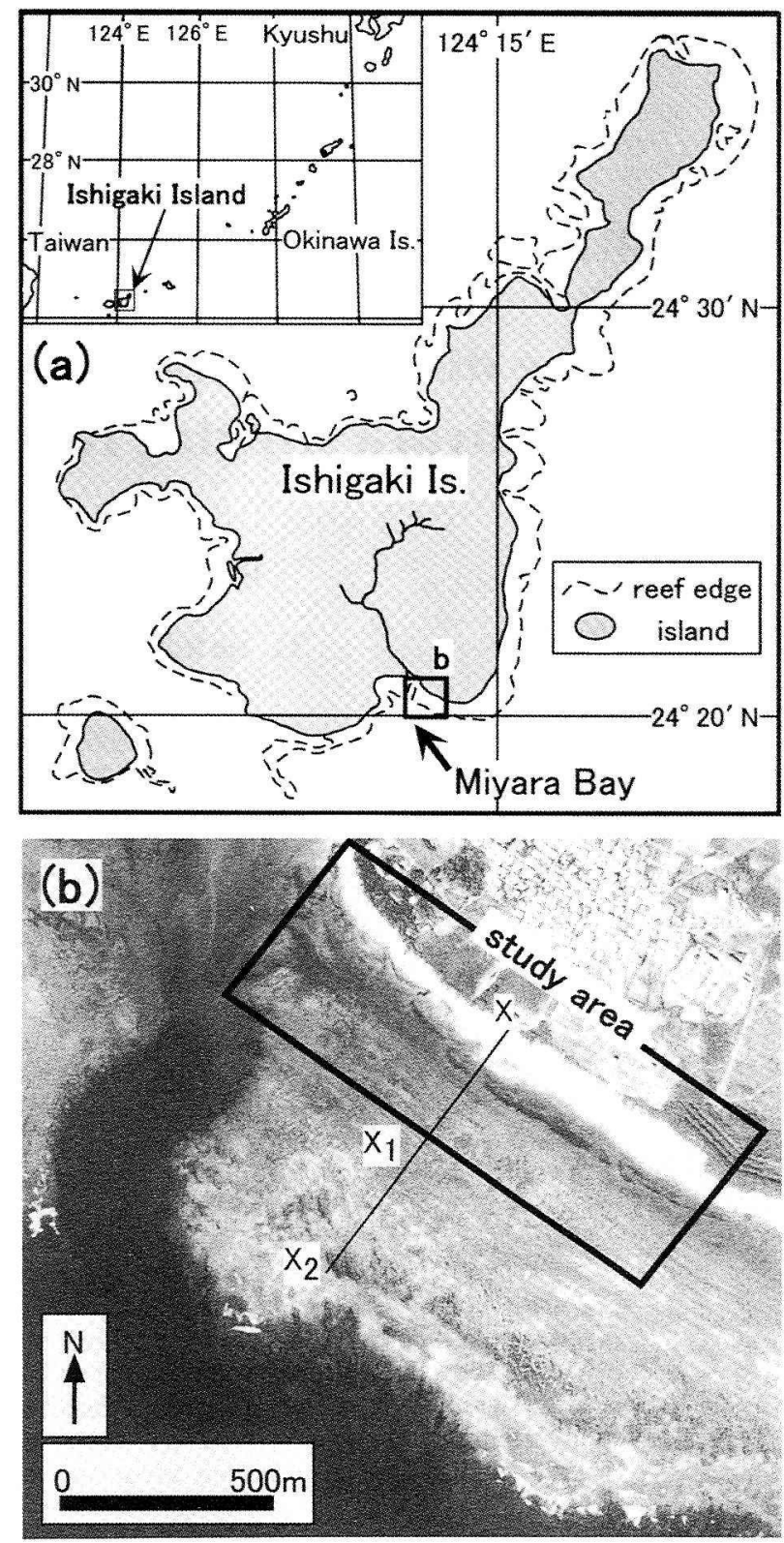

図1（a）研究対象地域 (琉球列島、石垣島)およひ (b) 宮良湾の空中写真（国土地理院1995年撮影） 直線 $X-X_{1}-X_{2}$ は地形断面 (図2b) の測線を示す

Fig. 1. (a) Map of the Ishigaki Island, the Ryukyus, Japan. (b) Aerial photograph of Miyara Bay taken in 1995. LineX $-X_{1}-X_{2}$ show the transect of microgeomorphological profile shown in Fig. $2 \mathrm{~b}$

コンパス（測定誤差士0.5）を用いた。

群体の生育状況は大きさ・外形・接地状態について調 査し、各項目を三段階に区分して記録した。大きさにつ いては、小型 (長径50～99cm）・中型（長径100 199cm） -大型（長径 $200 \mathrm{~cm}$ 以上）、外形については半球型・きの こ型・その他、接地状態については固着・傾倒・反転の カテゴリをそれぞれ設定した。外形における「きのこ型」 とは、群体下部の径が最大径より明らかに小さく、「きの 

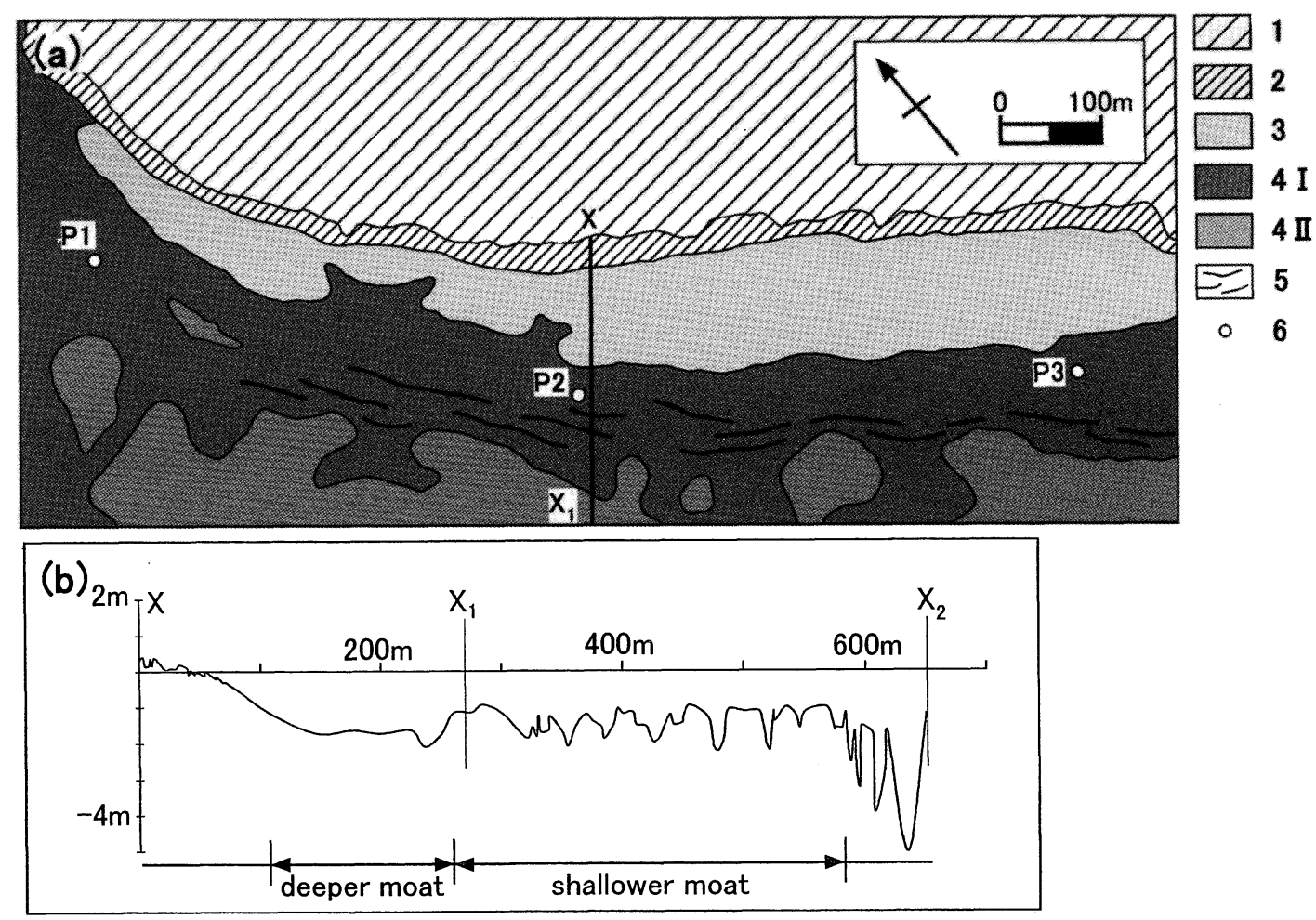

図 2 （a）宮良湾礁池の微地形分類および（b）裾礁の地形断面

1: 陸域 2: 海浜 3: 後方礁原 4: 礁池
6: 塩分計およひ流向・流速計の設置地点

Fig. 2. (a) Microgeomorphological map of the moat. (b) Topographical profile along the transect of fringing reef in Miyara Bay, Ishigaki Island.

1: Land, 2: beach, 3: inner reef flat, 4: moat ( I : deeper moat, II: shallower moat), 5: sandy stripes, 6: observation points where we set salinometers and current meter.

こ」に類似した外形を持つ群体を指す。これは、Done and Potts (1992) による「live hemisphere on dead inverted cone」および「overhanging “skirts”」をあつ群 体に相当する。また「その他」とは、サンゴ組織が残存 するものの骨格の侵食が著しく、群体が変形しているた め、「半球型」あしくは「きのこ型」に分類できない群体 の総称として設けたカテゴリである。

\section{流向・流速および塩分調查}

1999年 8 月12日から 8 月20日までの 9 日間、3つの観 測点（P1，P2，P3; 図2a）において、流向・流速および 塩分を観測した。調査域のほぼ中央に位置するP2には、 自記記録式の流向流速計（ACM- $8 \mathrm{M} ，$ アレック電子） と水温塩分計（ACT-16K，アレック電子）を設置し、調 査域縁辺部のP1およびP3には、小型水温塩分計（MDSCT，アレック電子）を設置して、それぞれ10分間隔で計 測を行った。さらにこの計測結果と石垣島気象台（石垣 市登野城）における降水量および風向・風速の観測結果 を比較し、礁池内の海水流動との関係を検討した。

また礁池内の海水流動と塊状ハマサンゴとの関係を把 握するため、調査域全体から無作為に選んだ半球型の 41 群体について、周囲に集積する砂質堆積物の堆積方向を
記録した。

\section{結 果}

\section{地形区分}

空中写真判読および現地での地形断面測量の結果から、 調査地域の裾礁を陸側から海浜、後方礁原、礁池、礁原 に区分し、さらに礁池を礁池深部之礁池浅部に細分した (図 2 )。これらの微地形は海岸線とほぼ平行に帯状の配 列をなしていた。礁原は頂面がほぼ低潮位の高さとなる 平坦面であり、礁池を隔てて海浜の沖側に広がる同様の 地形を後方礁原とした。礁池深部は、後方礁原から沖側 に続く起伏の少ない凹地形で、水深は約 $2 \sim 2.5 \mathrm{~m}$ である。 礁石灰岩上に主に砂質堆積物が広がり、部分的に石灰岩 基盤の露出もみられた。一方礁池浅部は、礁池深部から 沖側に続く緩やかに起伏する地形であり、水深は約 1 $2 \mathrm{~m}$ である。沖合に向かうにつれて堆積物が砂質から砂 砶質へと変化し、調査時（1998年 2 月）には海藻、特に ホンダワラ類（Sargassum spp.) が多くみられた。

\section{塊状ハマサンゴの分布および外形}

調査範囲（面積約 $147,200 \mathrm{~m}^{2}$ ）において確認された長径 


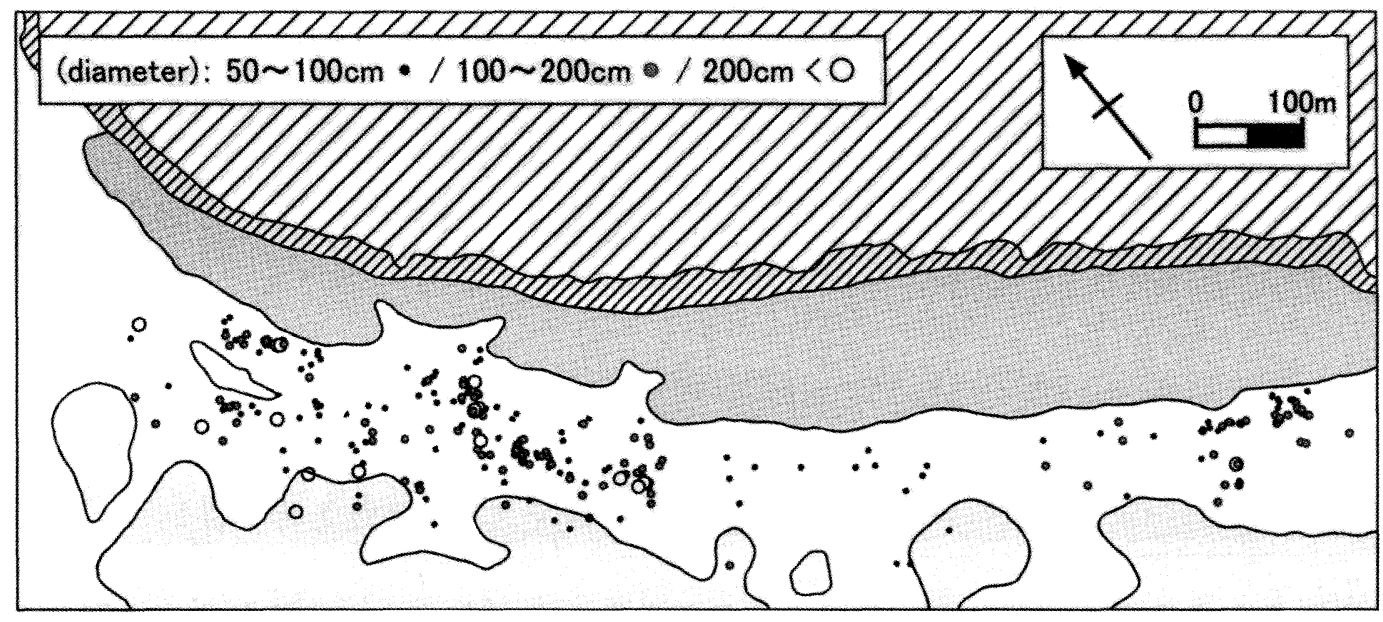

図 3 塊状ハマサンゴの分布

Fig. 3. Distribution of massive Porites in the moat.

$50 \mathrm{~cm}$ 以上（最大約 $350 \mathrm{~cm}$ ）の塊状八マサンゴは、 283 群体 であった（図 3 ）。平面図化した全群体の分布パターンを 明らかにするため、各群体を十分に小さな点と仮定し、 最近接群体までの距離についてランダム分布での期待頻 度と実際の分布の観測頻度の有意差を検定した。その結 果、ランダム分布は裹却され $\left(\chi^{2}=52354 ; d f=50, p\right.$ $<0.001$ 、、実際の分布は集中的であると判断された。ま た最近接群体までの平均距離に対する分散の割合は 6.81 であり、高い集中分布であるといえる。分布の集中域は、 中央北東部之北東部㧍よび南西部の後方礁原よりにある と考えられた（図 3 )。そこで、調查区内の分布が集中し ていると思われる地域を含む 8 地点において、20 $\mathrm{m}$ 四方 の方形区内にみられる塊状ハマサンゴ群体の数之方形区 の水深を比較した（図 $4 \mathrm{~b}$ )。その結果、水深の深い地域 ほど群体密度が高い傾向がみられ、水深之群体数の間に 有意な正の相関関係が示された $\left(r_{s}=0.51 、 n=32 、 p<\right.$ 0.01)。

外形に関してみてみると、一番多いのは半球型の群体 （図5a）で約51\%、きのこ型の群体（図5b）は約 $23 \%$ 、゙ あった。きのこ型群体は、基盤と接する部分が上部より 小さい不安定な形であり、基盤から離脱して転倒しやす いと考えられたため、きのこ型群体の接地状態を比較し た。きのこ型で転倒している群体の割合は、きのこ型群 体全体の約69\%であり、そのうち傾倒している群体が89 \%、反転している群体が $11 \%$ \%でった。傾倒している群 体について、基部からみた本来頂部にあたる部分が向い ている方向を群体の倒れている方向として計測すると、 倒れている方向は南東、南、東の順に多く、全体の $66 \%$ の群体が南東〜南であった（図6a）。

長径 $50 \mathrm{~cm}$ 未満の群体についての目視観察から、群体下 部が砂質堆積物に埋没しているすのの、基盤に固着して おらず簡単に動かすことができる未固着群体がいくつか みとめられた（図 $5 \mathrm{c}$ )。補足的に調查範囲内の 3 地点にお いて長径10～50cm末満のハマサンゴ属（塊状ハマサンゴ 以外の種む含む）の非固着群体数を計測したところ、0.5
群体 / $\mathrm{m}^{2}$ あ゙あた。

\section{流向・流速およひ塩分の経時変化}

調査地域の中央付近（P2；図2a）における流向・流速 の連続観測から、大潮〜中潮にかけて水道方向（北西） への一定した流れが観測され、特に下げ潮時に強まる $(30 \mathrm{~cm} / \mathrm{s}$ 以上）傾向がみられた（図 7 )。中潮〜小潮に向 かうに従い、流向は不安定となり流速も遅くなった。し かし熱帯低気圧が接近した 8 月20日には、小潮にも関わ らず北西方向への強い流れ（最大 $98 \mathrm{~cm} / \mathrm{s}$ ) が確認された。 観測期間中、気象台の記録では風向が南西〜南東で安定 し、夏季季節風の影響下にあった。また熱帯低気圧が接 近した 8 月20日以降、風向は南東となり風速も増加した。 このように今回の調查からは風向・風速と、流向・流速 に明瞭な対応関係は認められなかった。また群体の周囲 に集積する砂質堆積物の堆積方向は、70\%が北西であり (図6b)、傾倒したきのこ型群体が多く倒れている方向 （図6a）と正反対の方向にあった。

水道からの距離が異なる 3 点（P1，P2，P3; 図2a）で 塩分に大きな差異は認められなかったが、潮汐との関係 から変化のピークがずれる傾向が見られた（図 7 )。塩分 低下のピークはほぼ干潮時と一致し、最も水道から遠い P3から順にピークに達した。一方、塩分上昇のピークは 満潮に近い上げ潮時とほぼ重なり、同様にP3から順にピー クに達した。また、最も水道に近いP1において、13日の 大潮の満潮（8 時 4 分）直後の 8 時 40 分から約 1 時間 30 分、極端な塩分低下 $(33.2 \%$ から $26.4 \% 0)$ がみられ、同 時に水温の異常な上昇 $\left(28.3^{\circ} \mathrm{C}\right.$ から $\left.40.2^{\circ} \mathrm{C}\right)$ あ観測され た。調査期間中、上げ潮時から満潮時にかけての数時間、 宮良川起源と思われる濁水塊が調査範囲内に流入する様 子が観察され、特に降雨時に顕著にみられた。なお、期 間中 $1 \mathrm{~mm} / \mathrm{h}$ 以上（最大 $10.5 \mathrm{~mm} / \mathrm{h} ; 8$ 月 20 日 $12: 00$ ）の降 水は、8月12日 $8: 00 〜 11: 00 、 17: 00 、 13$ 日 $4: 00$ $(1.5 \mathrm{~mm} / \mathrm{h}) 、 20$ 日 $12: 00 、 17: 00 、 22: 00 \sim 23: 00$ に観測 された。 


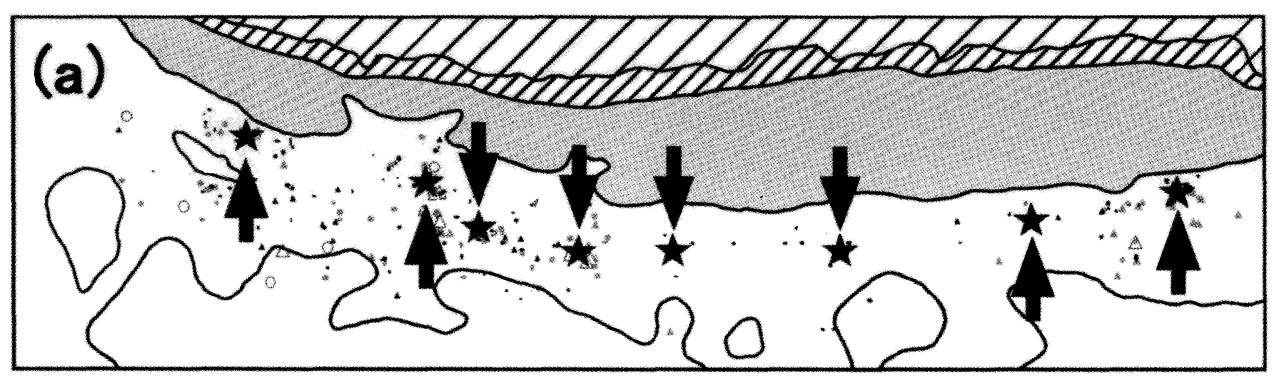

(b)

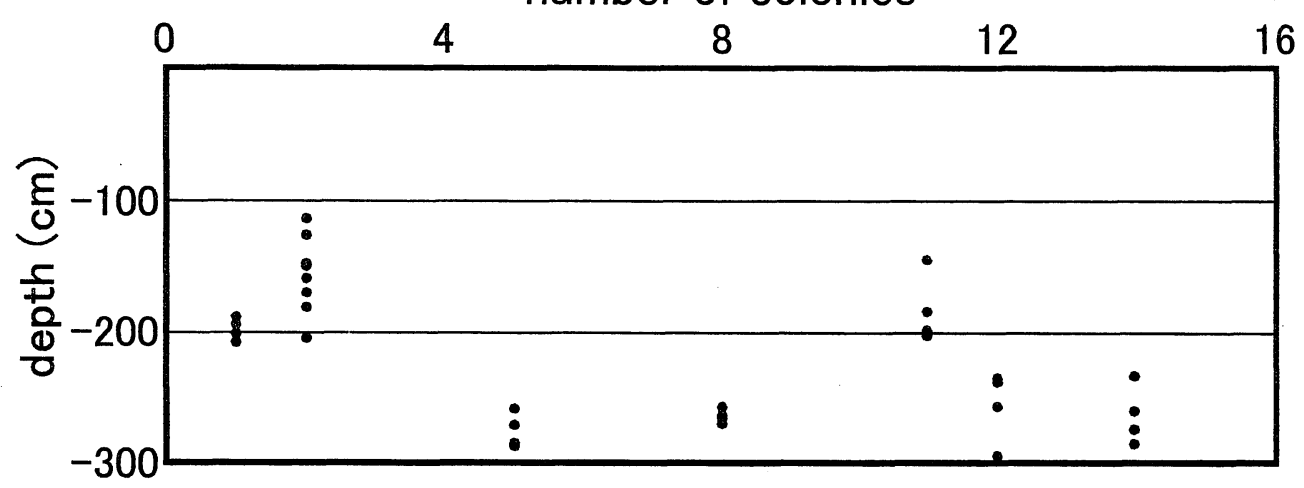

図 4 （a） 8 調査地点の位置および（b）各地点 $400 \mathrm{~m}^{2}$ 内の群体数と水深の関係

Fig. 4. (a) Location of eight sites. (b) Relationship between number of colonies in an area of $400 \mathrm{~m}^{2}$ and depth among each site.

\section{考 察}

\section{きのこ型群体の形成と海水の流動特性}

本調査で確認された塊状八マサンゴの約 4 分の 1 は、 接地状態として不安定なきのこ型の外形を呈していた。 これは、一定方向への顕著な流れがみられる砂質底の礁 池に群体があることから、砂質堆積物の挙動との関係が 大きいと推測される。本稿のきのこ型群体のように、群 体の基底接地部の径が最大径よりも明らかに小さくなる 現象は、塊状の Diploria strigosa (Hillis and Bythell 1998）やグレートバリアリーフにおける塊状ハマサンゴ (Done and Potts 1992) の例などが報告されており、そ の原因として、砂質堆積物による群体下部の埋積、ウニ などのグレーザーによる生物侵食、群体の巨大化による 群体下部の自己遮蔽の影響が挙げられている。本稿では、 直接的にきのこ型群体が形成される原因を明らかにする ことはできなかったが、砂質堆積物の定常的な移動が考 えられる地域での群体固着部全周のグレージングや、長 径 1〜2 $\mathrm{m}$ 程度の群体で自己遮蔽による群体下部の著し い生長阻害が主要因となる可能性は低いと考えられる。

大潮の下げ潮時に特に顕著にみられる北西方向への一 定した流れは、この海域の卓越流であると考えられる （図 7 )。卓越流は空中写真加ら確認された漂砂痕（図2a） と一致し、他の裾礁礁池で知られている海水の挙動とも 類似する (Suhayda and Roberts 1977; 山内ほか 1989)。
これは上げ潮時に礁嶺を超えて流入してきた海水が、下 げ潮時に礁池内を海岸線と平行に流れて礁嶺より低い水 道から排出される動きである。下げ潮時以外にも、熱帯 低気圧の接近時など外洋から激しい波によって礁池内へ 海水が流入することで、卓越流向に通常以上の強い流れ が生じている（図 7 )。このような海水流動の特性から、 礁池底の砂質堆積物は潮汐に合わせて日常的に移動・堆 積を繰り返す一方、台風など暴浪時には一斉に再移動し、 堆積状況を大きく変化させると考えられる。塊状八マサ ンゴは、定常的な砂質堆積物の堆積によって埋積される ことで群体下部が部分死し、生存している上部のみが生 長を続けることで群体下部より最大径が大きくなると推 測される。これが暴浪時に堆積物が取り払われることで 「“きのこ”の柄」の部分が露出するのだろう。そのため、 半球型にみえる群体でも、群体下部が堆積物に埋積され たままの潜在的なきのこ型群体はさらに多い可能性があ る。またきのこ型群体の約 $70 \%$ が頂部を卓越流向にむけ て倒れていたことは（図6a）、水中の構造物に対し砂質堆 積物が卓越流の下流側に多く堆積しやすいこと（図6b） と関係があるだろう。砂の堆積が群体の卓越流下流側で 進むことにより、群体下部の安定性に差が生じる。その ため暴浪時などに群体のバランスが崩れた場合、堆積物 によるの支えのない卓越流上流側に群体が傾くものと考 えられる。 

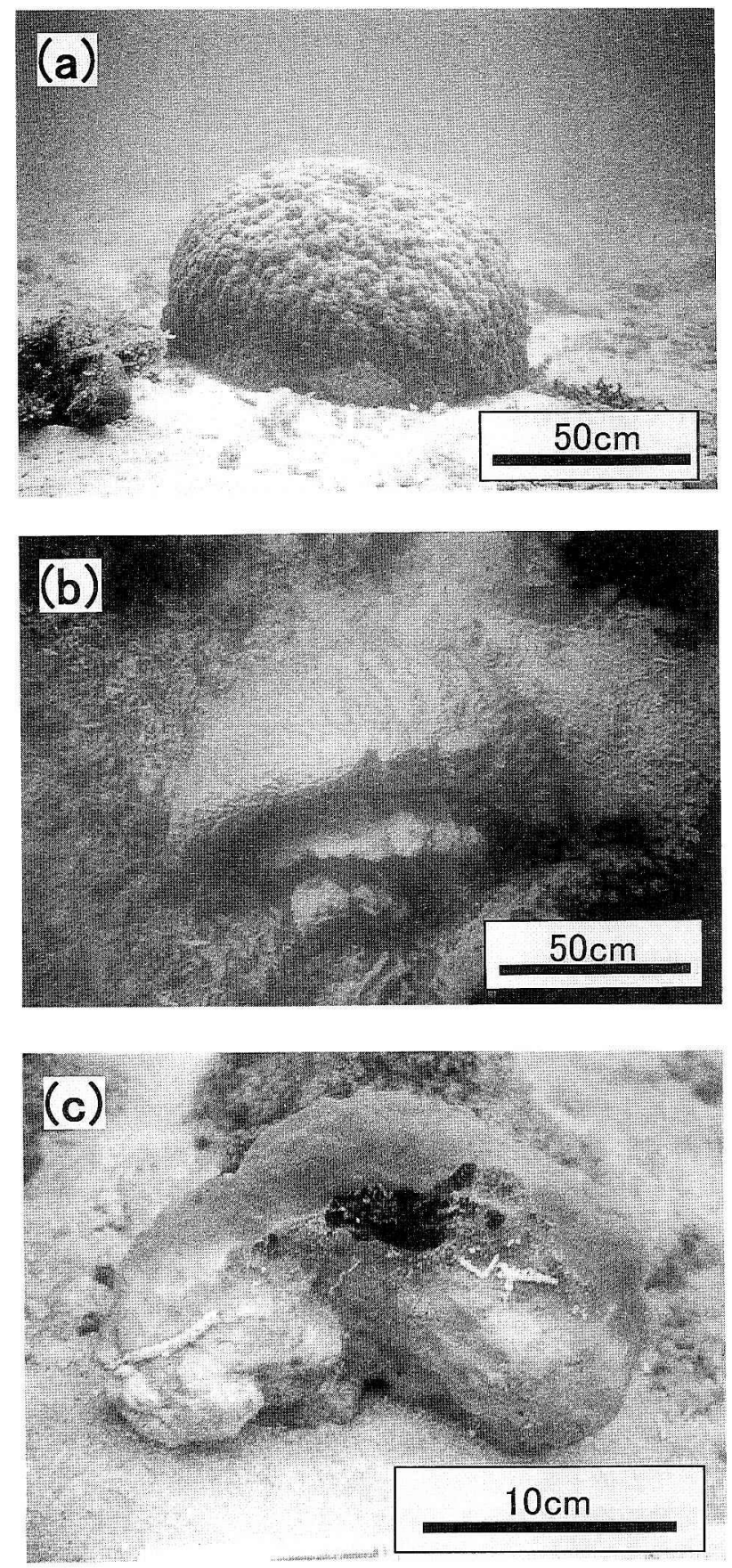

図 5 塊状ハマサンゴの外形と接地状態 （a）半球型群 体 （b）転倒したきのこ型群体 (c) 群体下部が 礁池底に埋没していた未固着の小群体

Fig. 5. Morphology and status of attachment of massive Porites. (a) Hemisphere shaped colony; (b) Mushroom shaped colony which turned sideways; (c) Small mobile colony which buried into the moat bottom. (a)

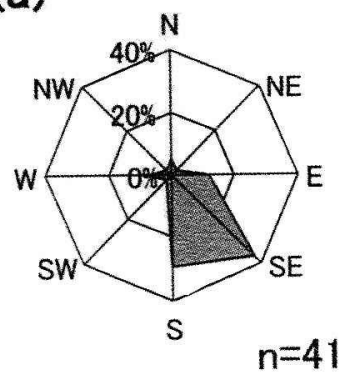

(b)

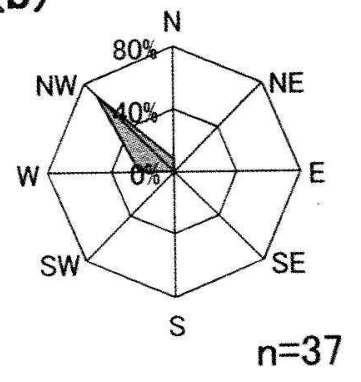

図 6 (a) 傾倒したきのこ型群体の倒れている方向およ ひ (b) 群体周辺に集積する砂質堆積物の堆積方向

Fig. 6. (a) Tilted direction rose depicts the dislodged mushroom shaped colonies. (b) Deposit direction rose depicts the sandy sediment around colonies.
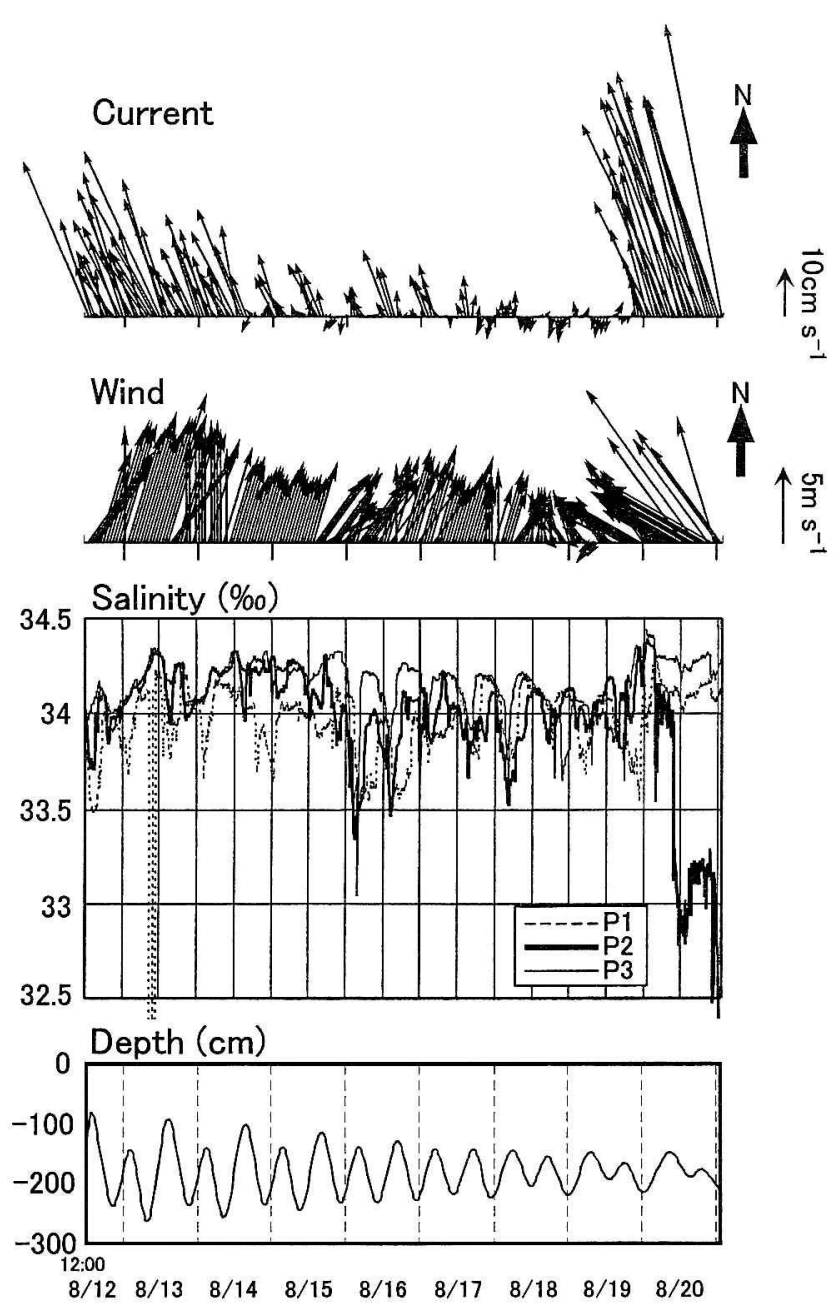

図 7 礁池における流向・流速、風向、塩分および計測 器の水深

Fig. 7. Hourly vector diagram of current and wind, and time series of salinity and water depth at current meter. 


\section{塊状ハマサンゴの分布特性とその制限要因}

本調査の塊状ハマサンゴは集中分布を示し、礁池内の 水深が深い地域ほど分布密度は高くなる傾向を示した （図 4 b)。この傾向は、塊状ハマサンゴの加入が主に可動 性群体 (mobile colony) によるものであることを示唆 すると考える。本調査域の礁池底はほぼ砂質であり、露 出している基盤の面積は少ない。そのため、造礁サンゴ の幼生着底基盤としては不安定な底質環境であり、幼生 による新規加入は困難である。Highsmith（1980）は、 エニウェトク環礁の砂質底の礁湖において、塊状ハマサ ンゴ群体の多くがより深くより波浪に遮蔽された安定性 の高い地域に多くみられることを指摘し、破片化した塊 状ハマサンゴが海水流動によって分散・加入したためと 推測した。本研究の結果は、この推測を定量的に裏付け るものと考える。またこれは、恩田（1999）による琉球 列島久高島の裾礁礁原における巨碟堆積物の分布調査か ら、暴浪時に縁脚から礁原に運び込まれた巨碩（塊状八 マサンゴの生組織が残存したものも含む）が、礁池のよ り深い地域に分布する傾向があることとも整合的である。 破片分散は、波浪などで比較的容易に壊れる枝状のミド リイシなどについて詳細な研究が行われている（Kobayashi 1984; Smith and Hughes 1999)。しかし、塊状のハマ サンゴなどであ、頻度は低いものの群体の一部あしくは 全体が離脱することが報告されている（DeVantier and Endean 1989; Massel and Done 1993)。本調査におい ても、きのこ型群体の転倒（図5b）や長径 $50 \mathrm{~cm}$ 未満で基 盤に固着していない群体（図5c）がみられ、塊状群体で あってあ全てが終始安定して固着・成長していないこと は明らかである。これは、塊状ハマサンゴの成長縞の解 析から、いくつかの群体で成長軸が途中大きく変化して いることからも間接的に示唆されるだろう（斎藤 1994）。 破片化による加入は、破片のサイズが大きく、かつ立体 的なものが生存の可能性が高い (Highsmith 1982; Smith and Hughes 1999)。つまりミドリイシ枝の破片など小さ く立体性に欠けるすのは、砂質堆積物の上に安定するこ とは難しく、埋没する可能性が大きい一方、塊状群体の 破片は、大きく立体的なサンゴ片となる潜在性をもつた め、生存する可能性が相対的に高くなる。よって、本調 查域のように海水流動により堆積物が移動しやすい海域 では、塊状ハマサンゴが特徽的にみられると考えられる。 なお、このような海水流動によって移動できる可動性群 体には、単に群体の一部が破片化したサンゴ片だけでは なく、破片化した後、固着する前に可動状態で何度も成 長軸を変化させ、全体的に生サンゴ組織で覆われた coralliths (Glynn 1974; Scoffin et al. 1985; Riegl et al. 1996）や基盤から離脱した群体全体、未固結の碟等 に着底した幼生が成長したあのなどあ含まれるであろう。 本調査域は赤土流出の顕著である宮良川に隣接するた め（沖縄県 1994）、河川水の礁池内への流入が塊状八マ サンゴの分布に影響を及ぼす可能性す考えられた。しか し、河川水流入の指標となる塩分の計測結果からは、宮 良川の影響による礁池内の塩分の慢性的な低下や、河口 からの距離に対応した塩分の明らかな勾配は認められな い（図 7 ）。また宮良川からの距離之塊状ハマサンゴの分 布にも明瞭な関係はみられず (図 3 )、本調査の空間スケー
ルでは、河川の影響が塊状ハマサンゴの分布を規定する 主要因とは考えにくい。一方、潮汐と同調する塩分の変 動に時間的なずれが観測され、水道に最む遠い卓越流の 上流側から先ピークに達する傾向がみられた。本調查域 の北東部にあたる白保海域の礁池における塩分変化の観 測から、礁池でみられる顕著な塩分低下は海岸から陸水 が流入することが原因と考えられている（Kawahata et al. 2000)。下げ潮時に陸域から流入する淡水、上げ潮時 に外洋から流入する海水が、卓越流によって水道方向に 移動する結果としてピークのずれが生じると考えられる。 しかし、現時点では礁池内のサンゴ群に対して、海岸か ら流入する陸水の影響を考察する有効なデータはなく、 今後さらに検討する必要があるだろう。

\section{謝 辞}

本研究に際し、琉球大学の Robert van Woesik 先生 には造礁サンゴの生態に関する貴重な情報およびご助言 を頂いた。また国士館大学の長谷川均先生、駒沢大学の 市川清士先生には石垣島のサンゴ礁に関して有益な助言 を頂いた。現地調查に際し、東京都立大学大学院生の室 伏多門 (現 (財) 日本システム開発研究所)、丸岡英生 （現（財）自然環境研究センター）、琉球大学学部生の山 本美和（当時）、駒沢大学学部生の工藤聖子各氏のご協力 を得た。東京都立大学の岡秀一先生、高岡貞夫先生（現 専修大学）には終始ご指導頂いた。また恩田真理子氏に は、本稿作成にあたり数多くの重要なご助言・ご協力を 頂いた。記してお礼申し上げます。本稿は東京都立大学 大学院に提出した佐藤崇範の修士論文 (1999 MS) に、 その後の調査結果を加えたものである。本研究の一部は 日本サンゴ礁学会第 2 回大会において発表した。

\section{引用文献}

DeVantier LM, Endean R (1989) Observations of colony fission following ledge formation in massive reef corals of the genus Porites. Mar Ecol Prog Ser 58: 191-195

Done TJ, Potts DC (1992) Influences of habitat and natural disturbances on contributions of massive Porites corals to reef communities. Mar Biol 114: 479-493

Fujioka Y (1999) Mass destruction of the hermatypic corals during a bleaching event in Ishigaki Island, southwestern Japan. Galaxea, JCRS 1: $41-50$

Glynn PW (1974) Rolling stones among the Scleractinia: mobile coralliths in the Gulf of Panama. Proc 2nd Int Coral Reef Symp 2: 183-198

長谷川 均・長谷川明雄 (1998) 琉球列島石垣島白保サンゴ礁 でみられるマイクロアトールの特徵一米原サンゴ礁との比 較をもとに一。国土舘大学地理学報告 7: 1-24

Highsmith RC (1980) Passive colonization and asexual colony multiplication in the massive coral Porites lutea Milne Edwards \& Haime. J Exp Mar Biol Ecol 47: 55-67

Highsmith RC (1982) Reproduction by fragmentation in corals. Mar Ecol Prog Ser 7: 207-226

Hillis ZM, Bythell JC (1998) "Keep up or give up": hurricanes promote coral survival by interrupting 
burial from sediment accumulation. Coral Reefs 17: 262

Hopley D (1982) The geomorphology of the Great Barrier Reef: quaternary development of coral reefs. WileyInterscience, New York

Kawahata H, Yukino I, Suzuki A (2000) Terrestrial influences on the Shiraho fringing reef, Ishigaki Island, Japan: high carbon input relative to phosphate. Coral Reefs 19: 172-178

Kobayashi A (1984) Regeneration and regrowth of fragmented colonies of the hermatypic corals Acrpora formosa and Acropora nasuta. Galaxea 3: $13-23$

Massel SR, Done TJ (1993) Effects of cyclone waves on massive coral assemblages on the Great Barrier Reef: meteorology, hydrodynamics and demography. Coral Reefs 12: 153-166

中森 亨 (1991) 沖縄県石垣島周辺海域および石西礁湖の造礁 サンゴ群集。目崎茂和編『石垣島のサンゴ礁環境』世界自 然保護基金日本委員会、57-72

沖緡県（1994）『沿岸海域実態調査（宮古島、石垣島及び西表島 並びに周辺離島)』沖縄県

恩田真理子（1999）琉球列島久高島裾礁における巨礫堆積物の 分布とその地形形成における役割。地理学評論 $72 \mathrm{~A}$ (11): 746-762

Riegl B, Piller WE, Rasser M (1996) Rolling stones: first report of a free living Acropora anthocercis (Brook) from the Red Sea. Coral Reefs 15: 149-150

斎藤 出 (1994）イシサンゴ骨格の密度模様と環境变動一琉球 列島を中心にして一。三重大学大学院人文社会科学研究科 修士論文

Scoffin TP, Stoddart DR, Tudhope AW, Woodroffe C (1985) Rhodoliths and coralliths of Muri Lagoon, Rarotonga, Cook Islands. Coral Reefs 4: 71-80

Smith LD, Hughes TP (1999) An experimental assessment of survival, re-attachment and fecundity of coral fragments. J Exp Mar Biol Ecol 235: 147-164

Suhayda JN, Roberts HH (1977) Wave action and sediment transport on fringing reefs. Proc 3rd Int Coral Reef Symp: 65-70

Takahashi T, Koba M, Nakamori T (1985) Coral reefs of the Ryukyu Islands: Reef morphology and reef zonation. Proc 5th Int Coral Reef Congr 3: 211-216

山内秀夫・長谷川均・長澤良太（1989）石垣島吉原のサンゴ礁 海岸における砂質堆積物分布について。沖縄地理 2: 1-12

(Date of acceptance: November 30, 2000) 